\title{
KECSKEMÉT FÖTERÉNEK KIMAGASLÓ ÉRTÉKEI: A FÁK
}

\section{THE OUTSTANDING VALUES OF KECSKEMÉT'S MAIN SQUARE ARE THE TREES}

\author{
Kiss Tímea ${ }^{{ }^{*}}$, Ecseri Károly ${ }^{1}$, Hoyk Edit ${ }^{2}$ \\ ${ }^{1}$ Kertészeti Tanszék, Kertészeti és Vidékfejlesztési Kar, Neumann János Egyetem, Magyarország \\ ${ }^{2}$ Agrárökonómiai és Vidékfejlesztési Tanszék, Kertészeti és Vidékfejlesztési Kar, Neumann János Egyetem, \\ Magyarország \\ https://doi.org/10.47833/2020.2.AGR.005
}

\section{Kulcsszavak: \\ zöldfelület \\ életkor meghatározás}

\section{Keywords:}

greening

age determination

\section{Cikktörténet:}

Beérkezett 2019. szept. 20.

Átdolgozva 2020. február 28.

Elfogadva 2020. március 5.

\begin{abstract}
Összefoglalás
Tanulmányunkban Kecskemét föterének fásszárú növényeit mértük fel és meghatároztuk ezek korát és értékét. Felmérésünkben közel 250 fa és cserje került be. Ezek összértéke 1,4 milliárd forint. A fák átlagos életkora 38 év, közülük a legfiatalabb fák 4 évesek, a legidősebb 96 éves.
\end{abstract}

\begin{abstract}
In our study, we evaluated the woody plants of the main square of Kecskemét and determined their age and value. In our survey included 250 trees and shrubs. The total value of these is HUF 1.4 billion. The average age of trees is 38 years, with the youngest trees being 4 years old and the oldest 96 years old.
\end{abstract}

\section{Bevezetés}

A településeken található fák a páratartalom növelésével, a por megkötéssel, zaj elnyeléssel, árnyékoló hatásukon keresztül a besugárzás csökkentéssel javítják környezetünket. Ezeket a hatásokat a fák ágrendszere, koronaformája és a lombozat révén fejtik ki [7][8]. Tehát a szabadterek értéke a nagyvárosokban a városi hősziget effektus (urban heat effect; UHI) mérséklésében és a vizuális/esztétikai hatásban mérhető le. Ugyanakkor a használattól független (nem közvetlenül emberi tevékenységhez kapcsolódó) értéket nehéz megbecsülni, hiszen pénzben kifejezett összeget kell rendelni olyan élő eröforrásoknak (növényeknek), amelyeket ténylegesen nem veszünk igénybe [12].

A fák környezeti hasznossága nyilvánvaló, hiszen kedvezően befolyásolják az adott terület mikroklímáját, legyen az egy park, egy fákkal borított közterület vagy fasorral szegélyezett úttest. De vajon, ha tényleges összegben akarjuk kifejezni mennyit is érnek ezek a fák milyen értékeket kapunk? Ezen értékbecslés elvégzésére több módszer is rendelkezésünkre áll (erdészeti, ipari, tüzelőanyag célú érték) [2], de legjobban talán az élő fák „eszmei” (pénzben kifejezett) értéke mutatja meg a közterületeinken található zöldvagyon jelentöségét. A fának, mint környezeti értéknek meghatározására szolgáló metodikák szintén több országban (Ausztrália, Amerikai Egyesült Államok, Nagy-Britannia, Németország) kidolgozottak, és ezeknek a szakirodalmi adatoknak a segítségével készítették el a hazai kutatók az általunk is alkalmazott értékbecslési eljárásokat [11]. A számított érték alapjául egységesen az aktív lombfelület méretét és egészségi állapotát veszik figyelembe [2].

\footnotetext{
* Kapcsolattartó szerző. Tel.: +36 76/517-655

E-mail cím: kiss.timea@kvk.uni-neumann.hu
} 
Tanulmányunkban - ezen módszerek segítségével - számszerüsítve szeretnénk bemutatni mennyit is érnek azok a fák, amelyek alatt nap, mint nap elmegyünk Kecskemét központjában. A Szabadság és Kossuth terén mértük fel az ott található fásszárú növényeket. Kecskemét megőrizte mezővárosias jellegét, de zöldfelületeinek aránya az elmúlt időszakban jelentősen csökken. 2009 és 2017 között a csökkenés több mint 30 \% volt. A közterületként használható zöldfelület nagysága egy före vetítve alacsony, 24,3 m²/fö [3]. Ezzel a Bács-Kiskun megyei székhely Brüsszel, München és Milánó mögé került a zöldfelületek ezen paraméterét tekintve [1]. Ezért is láttuk jelentőségét, hogy felmérjük és adatokkal igazoljuk, hogy a vizsgált területen található közel $250 \mathrm{db}$ fa milyen értéket is képvisel föterünk zöldfelületi rendszerében.

\section{Anyag és módszer}

\subsection{Mérések}

Első lépésben meghatároztuk a fásszárú növény faját és - amennyiben szükséges volt a fajtáját. A felmérés során minden egyes növény kapott egy egyedi azonosítót: tudományos név rövidítése és a felmérés során kapott sorszám (PI.: CO04 - Celtis occidentalis 4. a sorrendben). Összesen 243 darab növényt és 45 taxont rögzítettünk. A fajokat [9][13] alapján határoztuk meg, a növények rendszertani helyét pedig az aktuális kladisztikai adatbázisból (APG IV) gyűjtöttük ki [10]. Az érték meghatározásához szükséges meghatározni a fák korát. Ehhez szükség volt a fák törzskörméretének ismeretére, amelyet a fák talajfelszíntől mért egy méteres magasságában mértünk. A fák korának meghatározásához ezekböl az adatokból kiszámoltuk a törzsátmérőket így Radó [6] táblázatának segítségével, minden taxonhoz hozzá tudtunk rendelni egy megközelítő életkort.

\section{2. Érték meghatározás}

A faérték meghatározáshoz a Jószainé Párkányi Ildikó által kidolgozott növényértékelési módszert használtuk fel [4]. A cserjék értékmeghatározására Jámborné dr. Benczúr Erzsébet és munkatársa módszerét használtuk fel [5]. A napi faiskolai árat a Juniperus Kert 2019-20-as katalógusából és a Tahi Faiskola Kft. árjegyzékéből gyűjtöttük ki.

Ezek alapján a faérték meghatározása:

Faérték = napi faiskolai ár $\times$ kor szerinti szorzó $\times$ elhelyezkedési együttható $\times$ egészségi állapot szorzó.

Cserje érték: $=$ napi faiskolai ár $\times$ egyedi szorzó $\times$ elhelyezkedési együttható $\times$ egészségi állapot szorzó.

A kecskeméti fötér fás növényeinek értékét a fák és a cserjék együttesen adják.

\section{Eredmények}

A vizsgált állomány összetétele az 1. táblázatban látható. A taxonok listáját megvizsgálva megállapítható, hogy legnagyobb egyedszámmal a Celtis occidentalis, valamint a Styphnolobium japonicum fajok képviseltetik magukat. Emellett 10 példány feletti darabszám figyelhető meg a Corylus colurna, a Tilia cordata és a Tilia tomentosa esetében. A nemzetségek közül az Acer, a Fraxinus, a Picea, a Prunus, a Quercus és a Tilia génuszoknál lehetett megfigyelni 1-nél nagyobb fajszámot. A listában szereplő nemzetségek 23 családba sorolhatók, melyek közül a legtöbb génusz ( $5 \mathrm{db})$ a Rosaceae családból kerül ki. Emellett jelentős még a Cupressaceae és a Pinaceae család nemzetségek tekintetében. A darabszámot vizsgálva megfigyelhető, hogy a legtöbb példány Kecskemét föterén a Cannabaceae családba tartozik, de jelentős a Malvaceae és a Fabaceae taxonok száma is.

A cserje habitusú (illetve a tövétöl ágas) fásszárú növények száma alacsony ( 9 taxon $27 \mathrm{db}$ egyede) a törzzsel rendelkező növényekhez viszonyítva (36 taxon 216 példánya). A felmért területen magas azon taxonok száma $(20 \mathrm{db})$, amelyeknek mindössze egyetlen példányát ültették ki. A tü- és pikkelylevelü növényt az 1. táblázatban 8 esetben ( 26 egyed), míg lomblevelü örökzöldet 4 esetben 
(13 példány) lehet megfigyelni. A nemesített taxonok közül Kecskemét föterén találkozhatunk csüngő (Morus alba 'Pendula', Styphnolobium japonicum 'Pendula') és oszlopos (Populus nigra 'Italica', Prunus serrulata 'Amanogawa') fajtákkal is. Virágszínek tekintetében a sárga, illetve a fehér az uralkodó. Az alkalmazott fajok és fajták fő dekorációs értékét elsősorban a növények habitusában, valamint a vegetatív jegyeiben (levélmorfológia, lombszín) találjuk. A 45 taxon közül 13 olyan található, amely elfogyasztva mérgezést okozhat, ugyanakkor ezek közül mindössze 3 azok száma, amelyek súlyos vagy életveszélyes hatást válthatnak ki [8] a bélrendszerbe kerülve (Juniperus virginiana 'Grey Owl', Taxus baccata, Platycladus orientalis).

\section{Táblázat: A felmért fásszárú taxonok neve és darabszáma}

\begin{tabular}{|l|c|l|c|}
\hline \multicolumn{1}{|c|}{ TAXON NEVE } & DB szám & \multicolumn{1}{c|}{ TAXON NEVE } & DB szám \\
\hline Acer platanoides & 1 & Picea abies & 2 \\
\hline Acer pseudoplatanus & 2 & Picea pungens & 9 \\
\hline Acer saccharinum & 1 & Platanus orientalis & 1 \\
\hline Betula pendula & 3 & Populus nigra 'Italica' & 2 \\
\hline Cedrus atlantica & 1 & Prunus cerasifera 'Atropurpurea' & 2 \\
\hline Celtis occidentalis & 70 & Prunus avium & 1 \\
\hline Cornus sanguinea & 1 & Prunus serrulata 'Amanogawa' & 1 \\
\hline Corylus colurna & 15 & Pyracantha coccinea & 1 \\
\hline Cotinus coggygria & 2 & Quercus robur & 7 \\
\hline Crataegus $\times$ media 'Paul's Scarlet' & 1 & Quercus robur'Fastigiata' & 2 \\
\hline Fraxinus angustifolia subsp. pannonica & 1 & Quercus $\times$ turneri 'Pseudoturneri' & 1 \\
\hline Fraxinus excelsior & 2 & Styphnolobium japonicum & 26 \\
\hline Fraxinus pennsylvanica & 1 & Styphnolobium japonicum 'Pendula' & 1 \\
\hline Ginkgo biloba & 3 & Sorbus aria 'Magnifica' & 1 \\
\hline Ilex aquifolium & 9 & Sorbaria sorbifolia & 1 \\
\hline Juniperus virginiana 'Grey Owl' & 1 & Taxus baccata & 9 \\
\hline Larix decidua & 1 & Platycladus orientalis & 1 \\
\hline Liquidambar styraciflua & 2 & Tilia cordata & $\mathbf{2 4 3}$ \\
\hline Liriodendron tulipifera & 10 & Tilia tomentosa & 11 \\
\hline Metasequoia glyptostroboides & 2 & Tilia platyphyllos & 16 \\
\hline Morus alba 'Macrophylla' & 5 & Ulmus $\times$ hollandica & 3 \\
\hline Morus alba 'Pendula' & 7 & Viburnum rhytidophyllum & ÖsszESEN: \\
\hline Paulownia tomentosa & 1 & & 2 \\
\hline
\end{tabular}

$A z$ 1. ábrán a Fötéren található fásszárú növények közül a 21 jelentősebb egyedszámú taxont tüntettük fel. Az ábráról kihagytuk a cserjéket és azokat a növényeket, amelyekböl mindössze $1 \mathrm{db}$ található a felmért területen. Az adatokból átlagot számoltunk az egyes taxonok esetében, majd ezekből az eredményekből számítottunk egy összesített átlagot az ábrázolt 21 taxonra vonatkozóan. Így tehát az 1,0 (100 \%) a növények értéke esetében (szürke oszlopok) 4.990 .768 Ft-ot jelent, míg az életkor esetében (zöld oszlopok) 32 évet.

Az ismertetett 21 faj illetve fajta között 4 db nyitvatermő fa található, melyekből kettő (Gingko biloba és Metasequoia glyptostroboides) lombhullató. Az őshonos taxonok száma $8 \mathrm{db}$, a többi exóta származású. Szukcesszióban elfoglalt helyüket tekintve megfigyelhető, hogy klimax taxonokból kevés található a város központjában (Quercus robur és Picea abies) míg az előfutár fajok illetve ezek fajtái dominálnak a növénytársításban. A faj alatti rendszertani kategóriák közül 5 db fajtát figyelhetünk meg az 1. ábrán. Ezen fajták képviselik az alacsonyabb méretkategóriát a fák között 
(Morus alba fajták, illetve Prunus cerasifera 'Atropurpurea'). Emellett pedig egy fajhibrid (Ulmus $\times$ hollandica) is képviselteti magát a vizsgált területen.

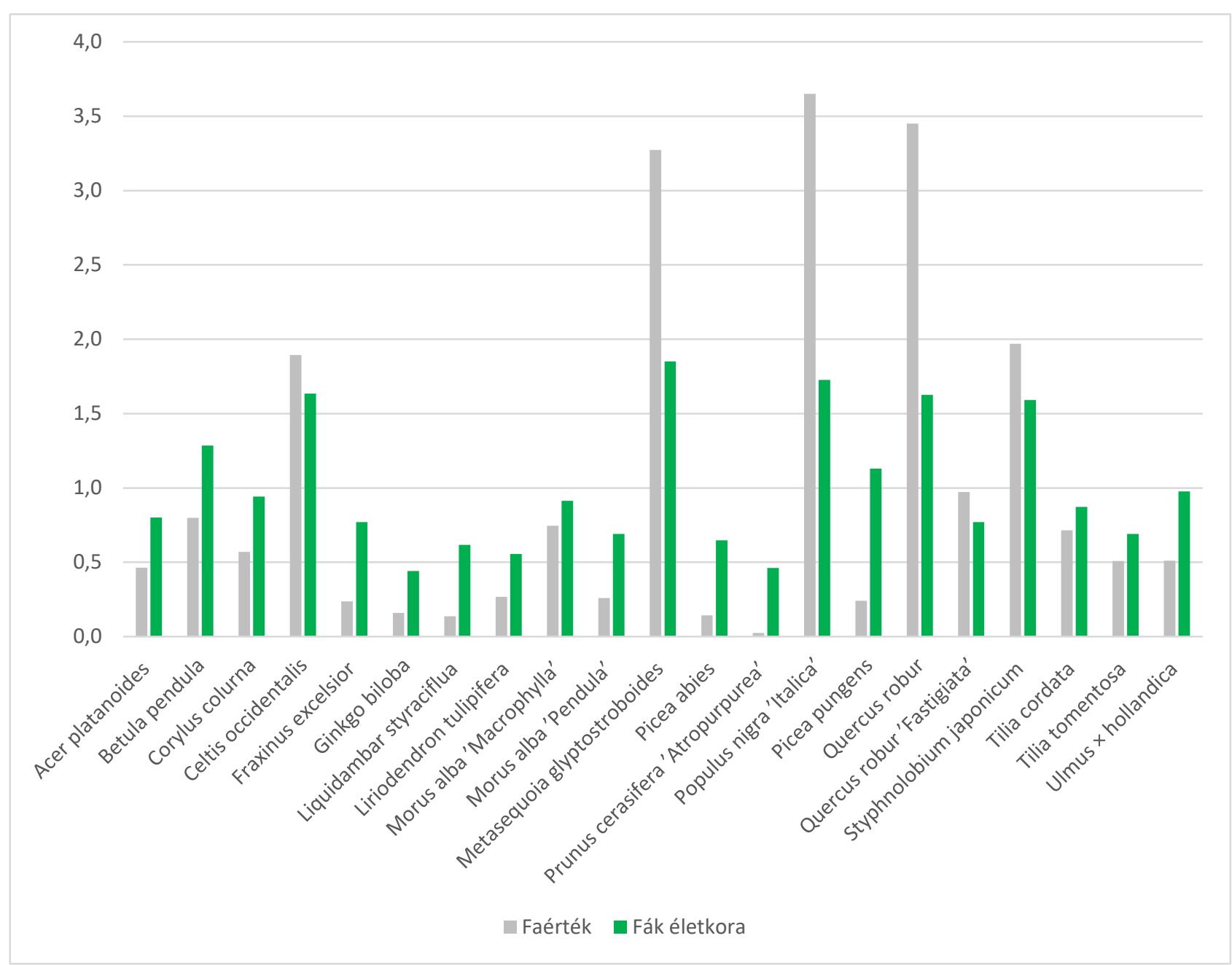

1. ábra. A 21 db jelentősebb taxon átlag faértékének és átlag életkorának arányai Megjegyzés: az 1,0 érték a faértékek esetében 4.990.768 Ft-ot, míg a fák életkorának esetében 32 évet jelent.

Az 1. ábra alapján megállapítható, hogy az állomány pénzbeli átlagértékét 5 taxon haladja meg: a Celtis occidentalis, a Metasequoia glyptostroboides, a Populus nigra 'Italica', a Quercus robur és a Styphnolobium japonicum. Ezen taxonok közül is legmagasabb átlagértékkel (16.338.000 Ft) az olasznyár egyedek rendelkeznek. Szintén 15.000.000 Ft feletti átlagértékkel rendelkeznek a kocsányos tölgy példányok, és a kínai ős-mamutfenyők is. Kiemelkedő még a japánakác és a nyugati ostorfa állományok értéke. 5 millió $\mathrm{Ft}$ alatti értéket az 1. ábrán bemutatott fák közül 16 taxon képvisel. A legkisebb pénzbeli átlagértéke a Prunus cerasifera 'Atropurpurea' állománynak van (126.000 Ft). 1 millió Ft alatti adatot figyelhetünk meg a Liquidambar styraciflua (680.000 Ft), a Picea abies $(718.650 \mathrm{Ft})$ és a Ginkgo biloba $(801.000 \mathrm{Ft})$ esetében is. A többi taxon átlagértéke 1 és 5 millió Ft között mozog.

Az életkor adatokat megfigyelve egy fiatal állomány képe rajzolódik ki az 1. ábrán. Az átlagos életkor adatok szórása jóval mérsékeltebb, mint az értékadatoké: a legidősebb taxon sem éri el az összállomány átlagának dupláját, valamint a legfiatalabb fa az átlag $44 \%$-át teszi ki. A 32 éves átlagéletkort (1,0 érték) meghaladó taxonok ebben a paraméterben a következők: Betula pendula (42 év), Celtis occidentalis (53 év), Metasequoia glyptostroboides (60 év), Populus nigra 'Italica' (56 év), Picea pungens (37 év), Quercus robur (53 év) és Styphnolobium japonicum (52 év). A legkisebb átlagéletkorral a Gingko biloba (14 év) és a Prunus cerasifera 'Atropurpurea' (15 év) egyedek rendelkeznek. 
Az egyes taxonok esetében a két átlagérték oszlopot összehasonlítva látható, hogy a $150 \%$ ot meghaladó értékkel és életkorral rendelkező növények pénzbeli értéke magasabb, mint a \%-ban kifejezett életkora, míg a 150 \% alatti kategóriába tartozó fák esetében ez az arány éppen fordított. Ez alól mindössze a Quercus robur 'Fastigiata' fajta a kivétel. A két oszlop közötti különbség is az értékes és koros egyedek (Metasequoia, Populus és Quercus) esetében a legnagyobb. A legkisebb differencia a Morus alba 'Marcophylla', a Tilia cordata és a Tilia tomentosa esetében mutatható ki (17, 16 illetve $18 \%)$.

\section{Következtetések}

A dendrológiai felmérés eredményei a Főtéren található állomány magas átlagértékét mutatták ki (közel 5 millió $\mathrm{Ft}$ ). Ez köszönhető a növények elhelyezkedésének (sürün beépített - fában szegény - terület), illetve a jó egészségi állapotnak. Ezen kívül a magas értéket képviselő taxonok a magas egyedi szorzónak köszönhetően értek el átlagérték feletti eredményt. Ezen taxonok közül dendrológiailag is kuriózumnak tekinthető a szökőkút mellett található $2 \mathrm{db}$ Metasequoia glyptostroboides. Az alacsony értékü taxonok elsősorban alacsony egyedi szorzójuknak (alacsony életkoruknak) köszönhetöen maradtak el az átlagtól.

Az állomány életkorát megnézve a Kecskemét Föterén található növényzet fiatalnak tekinthető. Ezt a kijelentést Schmidt, 2003 adataira alapozzuk, aki táblázatosan közli az egyes taxonok elöregedésének kezdetét városi környezetben [8]. Ezen információkat összehasonlítva az általunk becsült életkorokkal megállapítható, hogy az állományból mindössze 5 pionírnak számító egyed érte el az idős kort: az Acer saccharinum, valamint a 2-2 db Betula pendula és Populus nigra 'Italica'. Ezen fák fenntartására, ifjító metszésére (indokolt esetben pedig cseréjére) a fenntartónak fokozott figyelmet kell fordítani, ahogy ez látható is a két jegenyenyár esetében. Fontos ugyanakkor megemlíteni, hogy a fák törzskörméret adataiból számított életkor, illetve az ebből származtatott értékbecslés adatai csak támpontként szolgálnak ahhoz, hogy a zöldfelületek értéke számokban is kifejezhető legyen. Az egyes taxonok növekedése (törzsvastagodása) számos környezeti paramétertöl függ, és termőhelyenként, illetve egyedenként eltérő lehet.

\section{5. Összefoglalás}

A főtéren alkalmazott fásszárú állományról emellett elmondható, hogy alapvetően jól átgondolt és - a mindenkori lehetöségekhez képest - taxonokban gazdag zöldterület. A növényválasztás helyességét az idő mellett az egyedek aktuális jó egészségi állapota is igazolja. Több, kifejezetten várostürő fával is találkozhatunk (Fraxinus, Gingko, Styphnolobium, Celtis). Ez utóbbi két nemzetség képviselöi alkotják a teljes felmért terület egyedeinek 30 \%-át. Mindössze 1-2 esetben beszélhetünk környezeti vagy növényvédelmi problémák miatt lecserélendő példányokról (pl. Liquidambar styraciflua, vagy Ulmus $\times$ hollandica). Az állományra általában elmondható, hogy az abiotikus stresszhatásoknak igen jól ellenáll, ugyanakkor a fenntartónak és a városlakóknak kötelessége ezt a hatalmas értéket megőrizni és megvédeni az utókor számára.

\section{Köszönetnyilvánítás}

Köszönettel tartozunk a kutatás támogatásáért, amely az EFOP-3.6.2-16-2017-00012 „Funkcionális, egészséges és biztonságos élelmiszer termékpálya modell kidolgozása a szántóföldtől az asztalig elv alapján, tematikus kutatási hálózatban" pályázat keretében valósult meg. A projekt a Magyar Állam és az Európai Unió támogatásával, az Európai Szociális Alap társfinanszírozásával, a Széchenyi 2020 program keretében valósul meg.

\section{Irodalomjegyzék}

[1] Ferenczy T., Horváth Zs. (2014): Közösségi értékek gazdasági értékmeghatározása. GRADUS. Vol. 1. No. 1. 215 220. oldal.

[2] Horváth Zs., Ferenczy T. (2013): Élő értékeink vizsgálata a Kecskeméti Főiskola Kertészeti Főiskolai Kar zöldfelületén. Gazdálkodás és menedzsment tudományos konferencia. Kecskemét, 2013. szeptember 5. 178-182. oldal. 
[3] Hoyk E., Kanalas I., Farkas J. Zs., Szemenyei Gy. (2019): Környezeti kihívások a városfejlesztésben Kecskemét példáján. IN: Farkas J. Zs., Kovács A. D., Perger É., Lennert J., Hoyk E., Gémes T. (szerk.): Alföldi kaleidoszkóp: A magyar vidék a XXI. században: Tanulmányok a 70 éves Csatári Bálint köszöntésére. MTA KRTK Regionális Kutatások Intézete, Kecskemét. 133-146. oldal

[4] Jószainé Párkányi I. (2007): Zöldfelület-gazdálkodás, parkfenntartás. Mezőgazda Kiadó, Budapest.

[5] Ónody É., Jámborné Benczúr E. (2012): A ráckeresztúri templomkert fás növényeinek értékmeghatározása különböző számítási módszerekkel, Kertgazdaság. 44. évfolyam, 2. szám, 54-63. oldal.

[6] Radó D. (1999): Bel- és külterületi fasorok EU-módszer szerinti értékelése. A lélegzet 9. évf.,7.-8. számának melléklete. Levegő Munkacsoport, Budapest

[7] Radó D. (2001): A növényzet szerepe a környezetvédelemben. Zöld Érték Alapítvány és a Levegö Munkacsoport, Budapest

[8] Schmidt G. (2003): Növények a kertépítészetben. Mezőgazda Kiadó, Budapest

[9] Schmidt G., Tóth I. (2006): Kertészeti dendrológia. Mezőgazda Kiadó, Budapest.

[10] Stevens, P. F. (2001 onwards). Angiosperm Phylogeny Website. Version 14, July 2017. http://www.mobot.org/MOBOT/research/APweb/.

[11] Szaller V. (szerk.) (2012): Útmutató a fák nyilvántartásához és egyedi értékük kiszámításához. Magyar Faápolók Egyesületének kiadványa. 64-81. oldal

[12] Takács D. (2016): Városi szabadterek és szabadtér-fejlesztések ingatlanérték-befolyásoló hatásának elemzése Budapest példáján. Doktotri értekezés. Szent István Egyetem, Budapest 17-18. oldal

[13] Tóth I. (2012): Lomblevelü díszfák, díszcserjék kézikönyve. Tarkavirág, Budapest 